\title{
Mapping Petrarch in Seventeenth-century Italian Travel Writing
}

\author{
Nathalie Hester, University of Oregon
}

\begin{abstract}
Through a brief overview of seventeenth-century Italian travel writing, this article highlights the significant Petrarchan presence in this corpus. Petrarchan elements, from quotes of the Canzoniere to references to the poet-wanderer, are found in accounts that vary greatly in terms of itinerary, narrative style, and the author's reasons for traveling. For some Italian travelers, Petrarch is a fundamental point of reference in creating an authoritative "Italian" travel narrative, both in terms of literary echoes and in representing the traveler-narrator.
\end{abstract}

Petrarchism, broadly defined, reaches across many forms of textual production in Europe, including travel writing. Scholars such as Roland Greene, for example, have shown how Petrarchan notions of love were integrated into discourses on early modern empire by colonial European powers and in accounts such as those of Columbus. In seventeenthcentury Italian travel literature, Petrarch, both the figure of the poet and his ouvre, is a pervasive and indeed sometimes determining presence in this corpus. These significant Petrarchan elements point to a potential future direction for the Petrarch Project. Indeed, there could be a virtual space for mapping the reception of Petrarch in non-lyrical, more popular writing across geographical boundaries.

A brief foray into seventeenth-century Italian travel accounts reveals the reach of Petrarch's legacy, even in forms of writing that are traditionally considered nonliterary. Certainly travel writing, while historical in theory, in practice has always incorporated elements of literature. But in the period following Pietro Bembo's Prose della volgar lingua (1525), which established Boccaccio as the model for prose and Petrarch for that of poetry and helped codify the Italian literary canon, one finds in Italian travel writing more programmatic allusions to canonical texts, including Petrarch's Familiar letters and Rerum vulgarium fragmenta. In a travel culture associated more and more with European colonial expansion and proto-statehood, Italian travelers were progressively marginalized as a group. They turned to their literary heritage-a recognizable, internationally sanctioned form of cultural homogeneity-as a source of authority in their accounts and as a form of compensation for Italy's continued political fragmentation and its vulnerability to domination. The solution to Italy's historic placeless-ness was to establish Italy's literary heritage as the substitute "place" or home of Italy. ${ }^{1}$ Widely read and emulated, Italian literature offered a legimitizing backdrop for narrating the experience of travel.

In this context, Petrarchan currents inform many Italian travel accounts, from the humanist-courtier poet model in more literary travel writers' self-fashioning as characters and narrators, to the subtle, briefer, yet still meaningful allusions in the scientific or 
journalistic accounts of the late 1600s. Petrarch as peregrinus ubique, as homo viator, the "irrequieto turista," as Gianfranco Contini calls him, ${ }^{2}$ the scholar, the citizen of the world inscribing himself in text for posterity; the humanist who writes while navigating on the river Po, who despises sea travel, longs for otium, but continues to wander-all these facets of the Petrarchan oeuvre are at hand, directly or indirectly, unconsciously or not, as travelers leave an Italia that exists only in the imagination. The universalist, cosmopolitan Petrarch, poet and character, remains, even when only in fleeting glimpses, an inherent part of Italian perspectives and travel accounts. Especially in moments of difficulty and nostalgia, Italian travel writers sometimes inscribe themselves in the text as Petrarchan figures. $^{3}$

The epistolary travel account of Pietro Della Valle (1586-1652) is replete with Petrarchan resonances. His Viaggi (Travels, 1650-1663) reflects how Italian travelers, whether they have ostensible literary ambitions or not, almost reflexively incorporate Petrarchan allusions in their accounts. Della Valle, a Roman adventurer, collector, poet, musical composer, and master of self-fashioning, journeyed through Turkey, the Middle East, and India for twelve years (1614-1626), following his own itinerary and using his own funds. His account consistently and emphatically incorporates elements of Italian literary texts and genres, most notably Petrarchan poetics but also the epic and the pastoral. Della Valle initially dons pilgrim's garb, calls himself "il pellegrino" ("the pilgrim"), as the title page of his work indicates, and claims that the voyage is to serve as a respite from the tribulations of unrequited love. Like Petrarch (or Sincero of Sannazaro's Arcadia), Della Valle's geographical movement is, ostensibly, a restless search for spiritual and intellectual comfort and consolation. In some of his poetry, he blames his suffering-in language that recalls both Petrarch and Sannazaro—on his beloved, a woman named Beatrice Boraccio:

Amai nel Latio con quel cor sincero

che me diè il cielo, et in mille e mille prove

sempre hebbi costantissimo il pensiero:

ma la donna infedele, a cui fer nuove

voglie forse cangiar l'antica cura,

e collocarla indegnamente altrove,

poco la fede mia, poco la dura

servitù di dieci anni al fin prestando, ingrata altrui si dona, a me si fura.

Piangendo all'hor de la mia patria in bando

me ne andai disperato, e terre e mari

corsi non pochi, sempre sospirando.

In Latium I loved with the sincere heart that the heavens gave me, and I kept my thoughts constant through thousands and thousands of trials. But the unfaithful woman, whose new desires made her change her old cares and ungraciously place them elsewhere, paid little notice to my faithfulness and to the tenacious servitude I accorded her for ten years, and gave herself to another, and stole herself away 
from me. Weeping, then, I left my homeland, banished and desperate, and I traveled to not a few lands and seas, sighing always. ${ }^{4}$

The choice of terzine are a Dantean touch perhaps chosen because Della Valle also loved a Beatrice, but the flavor and lexicon of the poem are Petrarchan, especially in the final verses ("sempre sospirando"). For a traveler eager to reach posterity such as Della Valle, Petrarch and the Italian literary tradition remain automatic reference points. Likening his suffering to that of great Italian poets is an ideal strategy for obtaining fame and glory, which he did achieve in his lifetime.

Forty years later, a traveler without literary ambitions and with a more modest persona, Francesco Negri, left his hometown of Ravenna in 1663 and undertook a three-year voyage in Scandinavia. He was the first continental European to make an extensive journey through these northern regions. In Negri's epistolary account, Viaggio settentrionale (Northern Travels, 1700), literary culture comes to the fore in the moments when Negri recounts personal anecdotes. In one instance, as he faces exceedingly cold conditions and increasing isolation, Negri turns to the writings of the Italian literary and erudite tradition to express his emotional response. Traveling alone northward, Negri at one point loses a shoe in the deep snow and, when he finally retrieves it, is unable to put it back on because he no longer has feeling in his hands. He continues on nevertheless, carrying a shoe in one hand, and relates the event in Petrarchan tones:

In tal modo viaggiando, e sapendo che non è per finir questo sì scabroso viaggio in pochi giorni, ma che vi si ricercano settimane e qualche mese, e che sempre devono crescere difficoltà, io vado meco stesso parlando o ruminando in questa forma.-Tu soffri molto, Francesco, non è vero? Ma dimmi, chi ti ha fatto venir in queste parti? Nessuno. Ci sei venuto spontaneamente per veder le curiosità. Di chi dunque puoi lamentarti? (Negri 333)

Traveling in such a way, and knowing that this extremely rough journey will not end in just a few days, but instead will require weeks or even months, and that difficulties will always increase, I go on speaking and ruminating to myself in this way: You suffer greatly, Francesco, don't you? But tell me; who made you come to these parts? No one. You came spontaneously to see curiosities. About whom, then, can you complain?

In addressing himself by his first name, Francesco, and emulating the Tuscan poet's style ("io vado meco stesso parlando" "I go on speaking to myself”), Negri associates himself with the poet-pilgrim. In narrating moments of duress and implicit nostalgia for his patria, Negri turns back to his Italian literary roots for discursive models and expresses a specifically Italian sensitivity.

An end-of-century traveler from Calabria, Giovanni Francesco Gemelli Careri (16481724), explicitly addresses literary issues in his Viaggi per l'Europa (1693, 1701), an epistolary work recounting a 1686 trip to northern Europe. Gemelli Careri is best known for his Giro del mondo (Trip around the World) (1699-1700), the first account of an independent circumnavigation, but Petrarchan elements are more easily noted in his letters 
on Europe. The opening of the first letter of the 1693 edition of the Viaggi immediately foregrounds Petrarchan epistolary models: "Che a vostra signoria non sia ... discaro leggere in queste mie lettere familiari le mal composte notitie de' paesi che vado caminando" ("May it not be displeasing to your Lordship [Neapolitan lawyer Amato Danio] to read in these familiar letters of mine the poorly composed news of countries through which I go walking”) (Viaggi per l'Europa [1693] 1). In this typical apology for stylistic shortcomings, Gemelli Careri uses a Petrarchan-like utterance, "vado caminando," to bolster his authority as an Italian traveler and connects his letter writing to the Petrarchan epistolary model.

Gemelli Careri's letters about Venice, where he spends carnival before crossing the Alps, can be seen as a way to represent the city in Italian terms-that is to say, by means of an Italian literary language. Fascinated by Venice during carnival, Gemelli Careri takes stylistic liberties in order to evoke the festivities allowed before Lent. One element of his discursive playfulness is to quote from Petrarch's Canzoniere, so that the typical or expected rendition of reveling in Venice takes on a distinctly literary flavor, but with an irreverent twist. When describing the effects of the celebratory climate on his writing skills, Gemelli Careri uses exaggerated and self-mocking tones to reflect the extravagant behavior of merrymakers, including himself:

Di San Marco non occorre far parola questa volta, che troppo diverrei lungo e rincrescevole; riserbisi addunque alla settimana vegnente, tanto più, che dal vario stile, in cui piango, e ragiono in questa lettera, avrete voi per avventura compreso che la più parte del mio cervello s'è rimasta dietro la vanità del fugace secolo; e a volerlo porre sotto uno strettoio, non n'uscirebbe una gocciola di sugo, che valesse, Sì tra viato è 'l folle mio desio. (Viaggi per Europa [1701] 32)

This is not the proper time to speak of San Marco, because I would become too prolix and bothersome. Let us save that then for next week, so that you'll have understood, for the varied style in which I weep and speak, that most of my brain has followed the vanity of this fleeting life. And were my brain to be placed in a press, hardly one worthy drop of juice would be squeezed out. So far astray is my mad desire. ${ }^{5}$

These references to Petrarch, however playful, nevertheless evoke the ultimate model of literary expression.

Later on, when moving from historical and political topics to personal anecdotes, Gemelli Careri makes an explicit reference to Petrarch's wandering, ostensibly alluding to his own discursive and geographical wanderings:

Addio Vinegia, mi dite: e che digression Pindarica si è stata cotesta? Così tosto s'uscì di mente S[an] Marco. Confesso il vero ... io mi sono uno smemorato, e petrarchevolemente me ne sono ito Di pensier' in pensier, di monte in monte. (Viaggi per l'Europa [1701] 75) 
Farewell, Venice, you say. And what Pindaric digression has this been? I've forgotten San Marco so quickly. I shall confess the truth: I'm a forgetful one, and I have gone Petrarch-like from thought to thought, from mountain to mountain. ${ }^{6}$

The Italian perspective that Gemelli Careri constructs ultimately lies in the literary narration of the experience of travel, even before he arrives abroad. Venice during carnival provides the ideal pretext of discursive freedom for a literary Italian who is both traveling and travel writing—according to his newly coined adverb—-"petrarchevolemente."

Gemelli Careri's Petrarchan explorations into epistolary travel writing continue in the second volume of letters from his European travels that are part of the second edition of the Viaggi. The missives are marked as written from various cities on his way home from the siege of Buda, and later back to northern Europe, and then Madrid and Venice on separate trips. Mixing the epic themes of love and war, this volume consists primarily of letters addressed to French women. The focus on erudition, intellectualism, and literature comes to the fore in Gemelli Careri's letters to a certain Camillotta Pepini, which make up the central piece of this second volume. In the fiction of epistolary writing, he composes the letter after having returned to Naples and includes in it the only example of his own poetry in his travel writing:

A voi, che, più d'ogni altra cosa del mondo, tenete occupata la mia immaginazione, conviene, Madama, se pure non voglio volontariamente morire, ch’io dirizzi, dopo l'arrivo in Napoli, i primi tratti della mia penna [...] e parmi che questa città non sia più quella medesima; e non mi truovo cosa che appagar possa il mio desio, e mi cruccio, e mi adiro, e mi confondo, e farnetico; perché troppo altamente sono in me impresse le accorte, oneste, care, e leggiadre vostre maniere,

E ciò, che non è voi, Già, per lung' uso, il core odia, e disprezza.

Adesso sì, che parmi ver quell'amorosa metafisica del nostro Petrarca, la quale, come che non sia capita dall'ignorante volgo de' poetastri moderni; massimamente a coloro è affatto oscura, e nescosa, che non sanno o pur non hanno l'animo adattato a ricevere le vere impressioni di amore [...] ancor'io ho fatto un sonetto, che mai non si fu mio il mestiere di farne e benché sappia quanto voi siete valente nel poetare, anche nel nostro linguaggio, e che gite dietro la traccia degli ottimi scrittori, non mi ritengo perciò di mandarlovi: perocché non sarei veramente divenuto poeta, se non avessi una rabbia accanita di mandar fuori i miei parti (che un moderno direbbe aborti poeticl) senza aver tanta flemma di bene educarli, e di ripulirli. A voi tocca il corteggerlo [sic].

ite ardenti sospiri al dolce loco, ove colei, che del mio mal non cura,

Sen' sta sì fiera in vista, e sì secura

Prendendo amore, e sua possanza a gioco.

e quivi, armati di saette, e foco,

Stringete l'alma adamantine, e dura; 
tal che si volga a più pietosa cura,

E omai le incresca del mio pianger fioco.

voi le mie pene a lei narrate, e come

gridando vo, con affannata lena:

ahi, chi mi asconde il bel guardo soave?

Poi ven' tornate, con sue voglie dome,

a far la vita mia lieta, e serena,

Ch'or vile altrui, non ch'a me stesso è grave.

(Viaggi per Europa [1722], vol. 2, 197-98)

For you, Madam, who more than any other thing in the world captures my imagination, it is proper, lest I willingly wish to die, that I address to you the first strokes of my pen after arriving in Naples,... and it seems to me that this city is no longer the same, and that I am unable to find that which can satisfy my desire, and I suffer, and become angry and confused, and I ramble; because your clever, honest, affectionate, and graceful ways are too deeply impressed in me. And whatever is not you, my heart, by ancient habit, hates and scorns. And now our Petrarch's metaphysics of love does seem true to me, as much as it is misunderstood by those ignorant plebes that are bad modern poets, especially those to whom it remains obscure and hidden, because they do not know how or do not have a soul able to receive the true impressions of love.[...] And I have also composed a sonnet, which was never my profession to write, and despite knowing how talented you are in poetry, even in our language, and that you go about emulating great writers, I will not refrain from sending it to you; because I would not have truly become a poet if I had not had a furious desire to bring forth my creation (which a modern would call a poetic failure) without the calmness needed to refine and polish it. To you falls the task of correcting it.

Go forth, burning sighs, to that sweet place

Where she, who does not heed my suffering

remains, so proud to see, and so secure,

Taking Love and his power as but a game.

And there, armed with arrows and fire,

Besiege that hard and adamantine soul;

so that it will turn to more merciful concerns,

And so that she will take pity on my weakened laments.

go and tell her of my pain, and how

I go crying, short of breath:

ah, who hides from me that beautiful, gentle gaze?

and then return, with her will tamed,

To make my life happy and serene,

For now it is loathsome to others, and burdensome to me. ${ }^{7}$ 
Here, literary language is both discursive and meta-discursive, as Gemelli Careri comments on his writing and on poetic expression. The sonnet reflects Arcadian precepts for writing poetry: the language and imagery are Petrarchan and devoid of baroque conceits. He assesses the poetry of his contemporaries, much of which he appears to dislike. This poetic interlude helps represent Gemelli Careri as an Italian moderno-at once connected to northern European culture through his letters to Frenchwomen, but promoting Petrarch as the ultimate model for contemporary poetic expression and a legitimate symbol of Italian cultural renewal championed by academies such as the Arcadia.

These few examples suggest that, even in diluted form, Petrarchan poetics play a powerful role in early modern Italian travel writing. One can envision, perhaps in the not too distant future, a Petrarch Project that documents the far and broad reach of Petrarch's works into popular forms of textual production. A mapping of these instances where and when they occur could help us understand better the impact of Petrarch in a plurality of texts written "petrarchevolmente."

${ }^{1}$ For an elaboration of this notion, see Cachey, “An Italian History of Travel.”

${ }^{2}$ See Gianfranco Contini's introduction to his edition of the Canzoniere, xv, and Paolella, "Petrarca: peregrinus an viator?"

${ }^{3}$ For a more detailed treatment of Petrarchan characteristics in seventeenth-century travel writing see Hester, Literature and Identity in Italian Baroque Travel Writing.

${ }^{4}$ Translations are mine unless indicatd otherwise. The unpublished verses are conserved at the Biblioteca Estense Universitaria in Modena. See Speelman, 10. For more information on Della Valle's beloved, see Salvante, 20, n.15. Gaeta and Lockhart identify Della Valle's beloved as Belisa or Beatrice D’Avalos. See I viaggi di Pietro della Valle, xxiii.

${ }^{5}$ The translations into English of Petrarch's verses, Canzoniere 1, v.5, and 6, v.1, are from Petrarch's Lyric Poems, ed. and trans. Robert M. Durling, 36, 40. In the account, Gemelli Careri also quotes from Petrarch's Familiares.

${ }^{6}$ The verse is from Petrarch's Canzoniere, 129, v.1.

${ }^{7}$ The quote comes from Petrarch's Canzoniere, 116, vv.5-8: "et ho sì avezza / la mente a contemplar solo costei / ch'altro non vede, e ciò che non è lei / già per antica usanza odia e disprezza" ("and I have so / Accustomed / my mind to contemplate her alone that it sees nothing else, and / whatever is not she, already by ancient habit it hates and scorns"; Petrarch's Lyric Poems 224).

\section{Works Cited}

Cachey, Theodore, J. Jr. “An Italian History of Travel,” Annali d'Italianistica 14 (1996): 5564. Print. 
Della Valle, Pietro. Viaggi di Pietro Della Valle, descritti da lui medesimo in 54 lettere familiari. Mandate in Napoli all'erudito suo amico Mario Schipano. 4 vols. Rome: Mascardi, 1650-1663. Print.

---. I viaggi di Pietro Della Valle. Lettere dalla Persia. Eds. Franco Gaeta and Laurence Lockhart. Rome: Isituto Poligrafico dello Stato, 1972. Print.

Gemelli Careri, Giovanni Francesco. Viaggi per Europa. Naples: Giacomo Raillard, 1693.

---. Viaggi per Europa. 2 vols. Naples: Giuseppe Roselli, 1701-1704. Print.

Greene, Roland. Unrequited Conquests: Love and Empire in the Colonial Americas. Chicago, IL: University of Chicago Press, 1999. Print.

Hester, Nathalie. Literature and Identity in Italian Baroque Travel Writing. Burlington, VT: Ashgate Press, 2008. Print.

Negri, Francesco. Viaggio settentrionale. Ed. Enrico Falqui. Turin: Edizioni Alpes, 1929. Print.

Paolella, Alfonso. “Petrarca: peregrinus an viator?” Annali d'Italianistica 14 (1996): 152-76. Print.

Petrarca, Francesco. Canzoniere. Ed. Gianfranco Contini. Turin: Einaudi, 1964. Print.

---. Petrarch's Lyric Poems. Ed. and trans. Robert M. Durling. Cambridge, MA: Harvard University Press, 1976. Print.

Salvante, Rafaella. Il "Pellegrino" in Oriente: La Turchia di Pietro della Valle (1614-1617). Florence: Edizioni Polistampa Firenze, 1997. Print.

Speelman, Raniero. “Uno sconosciuto 'West-östlicher Divan' di Pietro della Valle.” EJOS 5(5) (2002): 1-38. Web. 26 Jan. 2011. <http://web.archive.org/web/20051103062858/www2.let.uu.nl/Solis/anpt/ejos/pdf5/Speelmanfin.pdf $>$. 